\title{
Redesain Visual Identity PSM Makassar
}

\author{
Baso Azwan Budiman \\ Desain Komunikasi Visual, Fakultas Seni dan Desain UNM \\ basoazwan01@gmail.com
}

\begin{abstract}
ABSTRAK
Perancangan ini bertujuan untuk meredesain logo dan membuat komponen visual identity untuk Persatuan Sepakbola Makassar (PSM Makassar). Kumpulan data dalam perancangan diperoleh melalui studi pustaka, observasi, maupun wawancara kepada supporter, manajemen, dan pengamat sejarah Persatuan Sepakbola Makassar (PSM Makassar). Konsep desain yang diusung dalam perancangan kali ini adalah "Semangat Kejayaan". Semangat kejayaan adalah suatu istilah yang menggambarkan mengenai suatu sikap dimana seseorang atau kelompok yang memiliki semangat dan ambisi dalam berjuang mencapai tujuannya serta memiliki tekad yang kokoh untuk terus berjuang demi mendapat kejayaannya. Seperti yang diketahui Persatuan Sepak Bola Makassar (PSM) adalah klub besar di Indonesia yang setiap musimnya selalu di perhitungkan di liga Indonesia bahkan di asia dan menjadi salah satu tim dengan prestasi paling stabil di liga Indonesia. Masa kejayaan PSM Makassar adalah saat menjadi juara liga Indonesia pada tahun 2000 dengan hasil yang sangat mengesankan hanya kalah 2 kali dari 31 pertandingan. Sementara di level internasional Persatuan Sepak Bola Makassar (PSM) tercatat 1 kali berlaga di Piala Winner Asia dan 3 kali mewakili indonesia di liga Champion Asia bahkan Persatuan Sepak Bola Makassar (PSM) pernah lolos ke perempat final liga Champion Asia pada tahun 2000. Sejarah tentang masa kejayaan Persatuan Sepak Bola Makassar (PSM) di masa lalu yang menginspirasi konsep desain yang di usung dengan harapan melalui perancangan kali ini dapat membuat Persatuan Sepak Bola Makassar (PSM) kembali ke masa kejayaannya atau bahkan bisa melampaui prestasi yang telah dicapai.
\end{abstract}

Kata Kunci: Visual; Identity; Redesain; PSM Makassar.

\begin{abstract}
This design aims to redesign the logo and create a visual identity component for the Makassar Football Association (PSM Makassar). The data collection in the design was obtained through literature studies, observations, and interviews with supporters, management, and historical observers of the Makassar Football Association (PSM Makassar). The design concept that was carried out in the design this time was "The Spirit of Glory". The spirit of glory is a term that describes an attitude where a person or group that has enthusiasm and ambition in achieving its goals and has a strong determination to continue to fight for its glory. As is known, the Makassar Football Association (PSM) is a big club in Indonesia, which every season has always been taken into account in the Indonesian league even in Asia and has become one of the most stable teams in the Indonesian league. PSM Makassar's heyday was when it won the Indonesian league in 2000 with very impressive results which only lost 2 of 31 matches. While at the international level the Makassar Football Association (PSM) was recorded 1 time competing in the Asian Winner Cup and 3 times representing Indonesia in the Asian Champions League even the Makassar Football Association (PSM) had qualified for the Asian Champions League quarter-finals in 2000. the heyday of the Makassar Football Association (PSM) in the past that inspired a design concept that was
\end{abstract}


stretched with hope through design this time could make the Makassar Football Association (PSM) return to its heyday or even surpass its accomplishments.

Keywords: Visual Identity, Redesign, PSM Makassar.

\section{PENDAHULUAN}

Sepak Bola adalah sebuah permainan yang dikenal oleh bangsa eropa sebagai permainan kelas pekerja. Permainan yang tidak mengenal sekat dan batas kemanusiaan, hanya pada sepak bola lah manusia menjadi satu sama lain. Sejarah mencatat bahwa bangsa Aztec pernah memainkan sebuah permainan yang kurang lebih sama dengan sepak bola sebagai bentuk pemujaannya kepada Yang Maha Kuasa dan akhirnya bangsa Eropa datang dan mempelajari permainan tersebut (Qosasih, 2018: xii).

Di Asia, Seperti yang kita tahu, sepak bola adalah sebuah permainan yang sangat populer. Namun akan lebih jauh tinggi lagi popularitasnya, saat melihat Indonesia yang menjadikan sepakbola sebagai "agama". Tak terbayangkan betapa besar gairah orang Indonesia terhadap sepak bola (Gaspar, 2018: ix). Penggila sepakbola di Indonesia mungkin adalah yang paling passionate dibandingkan bangsa manapun di asia. Apapun yang terjadi pada federasi sepak bola di Indonesia, kebobrokan apapun yang ada, stadion-stadion yang tak juga dibenahi serta lapangan yang tak rata dan bangku patah yang bersandar di tribun; di Indonesia stadion akan selalu penuh, apapun yang terjadi! (Gaspar, 2018: xi).

Indonesia sama sekali tidak terlambat mengenal sepakbola. Para pelaut Portugis memperkenalkan permainan ini di sudut kepulauan banda sekitar abad ke-18. Sementara para pelaut Belanda yang lama pergi dari tanah airnya, pertama kali melihat permainan ini justru di Bandar Jayakarta, kala dimainkan oleh para kuli; dan bukan di Bandar Rotterdam ataupun Genoa. Para kuli pribumi, Melayu, Cina, Arab atau Eropa memainkan bola bersama para pelaut Belanda, Inggris dan Spanyol yang saat itu ramai di Jayakarta. Nusantara telah mengenal sepakbola sejak lama, bahkan ketika kita masih menjadi warga kelas dua dunia. Meski demikan, bangsa kita bukan kelas dua pada dunia sepakbola. Sejarah bahkan tak banyak mencatat nama Eropa yang menjadi kebanggaan di dunia sepakbola, karena nama asli Nusantara atau Cina-lah yang lebih dikenal pada masanya (Qosasih, 2018: xv).

Sepak bola Indonesia butuh apa yang dinamakan gairah. Cintailah atau benci saja padanya, keduanya bisa membuat kita bergairah untuk menyaksikannya. Bagaimanapun ada beberapa diantara kita yang tetap mencintainya apapun yang terjadi. Mereka yang mencintai sepak bola Indonesia adalah mereka yang mencintai Indonesia sepenuh hati mereka (Scheunemann, 2018: xvii).

Tak perlu lagi bertanya panjang lebar dan sebesar apa gairah bangsa Indonesia pada sepak bola. Puja-puji akan potensi selalu ada pada gimmick setiap tulisan tentang sepakbola Indonesia. Pemaparan pada gairah dan kebesaran nama sepak bola tak usah lagi dipertanyakan. Lalu mengapa Indonesia terus menerus berada di papan bawah sepakbola dunia? (Sutton, 2018:1). Gairah sepak bola Indonesia dapat dilihat dari para supporter fanantik yang ada bahkan selalu terjun ke medan perkelahian dan tak segan-segan memukuli siapapun yang menjadi lawannya. Kefanatikan supporter Indonesia juga bisa dilihat dari seorang pedagang yang berjualan di pasar tradisional yang rela menutup warungnya jika tim kesayangannya bertanding (Sutton, 2018:44).

Di Makassar sendiri perkembangan sepak bola sangatlah pesat, itu terbukti dari di 
dirikannya Makassaarche Voetbalbond atau MVB pada tanggal 2 November 1915 dan menjadi klub sepak bola tertua yang ada di Indonesia. Menurut pengamat sejarah Muh. Nur Imam Martono S.H, seiring kedatangan Jepang ke Indonesia pada tahun 1942, banyak hal-hal yang berbau Belanda di hapuskan dan pada tahun 1950 Makassaarche Voetbalbond resmi berganti nama menjadi PSM Makassar (Martono, 2019).

Fanatisme sepak bola di Makassar bisa dilihat dari supporter yang memadati jalanan kota ketika tim kebanggaan Kota Makassar tersebut bertanding, hingga ada yang rela mengeluarkan uang pribadi mereka hanya untuk bertandang ke kandang lawan ketika PSM Makassar bertanding. Menurut Daeng Uki yang merupakan Panglima Kelompok Suporter Laskar Ayam Jantan, PSM Makassar bukan lagi klub sepakbola yang harus di dukung, di teriaki, di soraki, tetapi bagi warga Makassar PSM adalah sebuah harga diri yang harus di junjung tinggi dan membela PSM adalah seuatu kewajiban bagi warga Kota Makassar (Uki, 2019). Sementara menurut Bapak Zul Daeng Kulle Selaku presiden dari Kelompok Suporter Redgank mengatakan bahwa PSM Makassar saat ini bukan hanya sebuah tim sepak bola tetapi juga menjadi sebuah identitas bagi masyarakat Sulawesi Selatan khususnya masyarakat Kota Makassar. Bahkan menurut Daeng Kulle ketika orang menyebut Kota Makassar yang pertama terlintas di kepala mereka adalah PSM Makassar bukan lagi tentang Karebosi dan keindahan sunset di Anjungan Pantai Losari (Kulle, 2019).

Sebagai sebuah identitas bagi warga Kota Makassar, PSM dijuluki oleh rival mereka sebagai Ayam Jantan Dari Timur yang identik dengan Merah sebagai warna kebersaran dan menjadi branding PSM Makassar. Dengan sejarah panjang serta prestasi yang telah dicapai branding sangat penting bagi klub sepak bola sebesar PSM Makassar yang terkenal dengan permainan keras dan cepat serta menjadi salah satu kekuatan sepak bola Indonesia khususnya di Indonesia Timur.

Seperti yang sudah diketahui brand adalah sebuah nama, simbol, desain ataupun gabungan dari semuanya yang dipakai untuk mengidentifikasi sesuatu. Artinya, sesuatu boleh dikatakan sebuah brand jika bisa mengidentifikasikan sesuatu, dan saat brand tersebut berinteraksi serta menyapa audiencenya, maka brand tersebut sedang melakukan proses branding (Permana,2012:1). Ketika berbicara tentang brand kita juga berbicara tentang logo karna menurut Irvan Permana (2012:101) brand dan logo adalah dua hal yang tidak terpisahkan dan mempunyai fungsi saling melengkapi satu sama lain untuk membuat suatu entitas menjadi berbeda dan mempunyai daya saing diantara kompetitornya.

PSM Makassar sampai saat ini telah 2 kali mengganti logo yang pertama sangat identik dengan logo pemerintah Kota Makassar dan yang kedua di launching pada hari Jumat tanggal 14 April 2017. Menurut Dg. Kulle penggantian logo PSM Makassar dinilai sangat tepat karna adanya peraturan Menteri Dalam Negeri Nomor 32 tahun 2011 dan 39 tahun 2012 tentang penghentian anggaran kepada klub profesional dan merupakan suatu keberanian dari manajemen klub PSM Makassar. Pada saat setelah launching logo terbaru PSM Makassar terjadi banyak polemik dan kontroversi karna logo PSM yang terbaru di nilai sangat mirip dengan logo salah satu klub besar Eropa yang ada di Inggris yaitu Arsenal.Kontroversi juga terjadi di dunia maya, banyak netizen di Indonesia menilai logo terbaru PSM Makassar adalah hasil menjiplak dari logo Arsenal. Sebagai klub sepak bola tertua dan salah satu klub besar yang ada di Indonesia, dengan sejarah yang panjang dan prestasi yang telah di raih serta sebagai identitas dari warga Kota Makassar tidak seharusnya PSM Makassar menjadi bahan ejekan bagi pendukung klub 
sepak bola dari daerah lain karna sebuah logo yang dinilai menjiplak logo Arsenal. Namun itulah Indonesia, kefanatikan supporter klub sepak bola di Indonesia yang sangat tinggi yang membuat semua itu terjadi.

Kontroversi tentang logo terbaru PSM Makassar yang terlihat sangat mirip dengan logo Arsenal dinilai Daeng Uki sebagai hal yang biasa karna menurutnya filosofi yang terkandung di dalam logo PSM Makassar dan logo Arsenal di yakini tidak ada kesamaan. Muhammad Akbar sendiri sebagai kreator logo terbaru PSM Makassar tidak memungkiri bahwa karyanya memang terlihat mirip dengan logo Arsenal dia juga mengatakan tidak ada unsur kesengajaan di dalamnya. Menurut Muhammad Akbar yang membuat logo PSM Makassar saat ini terlihat mirip dengan Logo Arsenal adalah garis putih berbentuk "V" di sisi kiri dan kanan tapi menurutnya itu di tambahkan murni untuk membuat warna merah pada logo tersebut terlihat lebih dominan dan tidak terlihat kaku di mata.

Dari penjelasaan diatas dapat dirumuskan beberapa masalah yaitu 1). Logo PSM Makassar saat ini terlihat mirip dengan logo Arsenal, 2). PSM Makassar tidak memiliki visual identity.
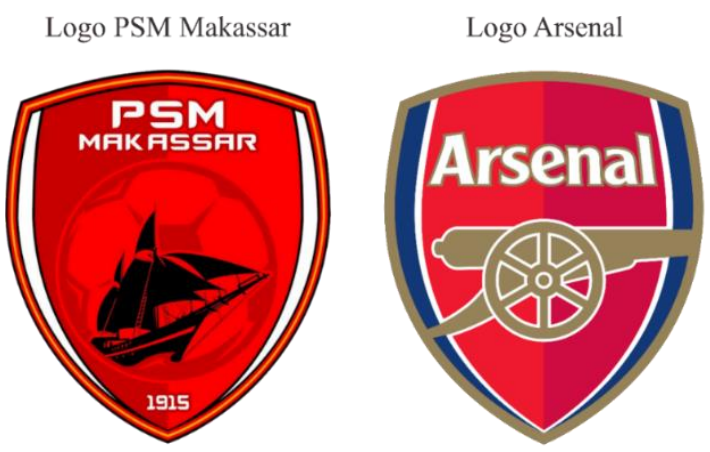

Gambar 1. Logo PSM dan Logo Arsenal

Adapun tujuan penelitian kali ini yaitu 1). Redesain logo PSM Makassar, 2). Merancang logo yang dapat menjadi identitas PSM Makassar, 3). Merancang logo yang dapat mewakili harapan warga kota Makassar khususnya harapan supporter PSM Makassar, 4). Merancang logo yang menarik dan dapat diterima oleh warga kota Makassar khususnya supporter PSM Makassar.

Redesain visual identity kali ini membutuhkan beberapa landasan teori sebagai identifikasi permasalahan yang diangkat. Menurut Kamus Besar Bahasa Indonesia (KBBI) redesain adalah proses perancangan ulang. Sementara menurut Departemen Pendidikan dan Kebudayaan Republik Indonesia redesain bersal dari Bahas Inggris yaitu Redesain yang berarti mendesain kembali atau perencanaan kembali. Dapat juga berarti menata kembali sesuatu yang sudah tidak berfungsi lagi sebagaimana mestinya. Jadi redesain dapat diartikan sebagai desain ulang yang dapat mengacu dari sebuah perencanaan dan melakukan sebuah perubahan untuk manfaat yang lebih baik dari sebelumnya.

Dalam Kamus Brand A-Z Visual Identity atau identitas visual merupakan sebuah brand, termasuk di dalamnya logo, huruf, (tipografi) kemasan, iklan, sign system, seragam, dan sistem literatur (Wirawan, 2008).

Logo merupakan bentuk gambar atau sekedar sketsa dengan arti tertentu, mewakili suatu arti dari perusahaan, daerah, perkumpulan, produk, negara, dan hal-hal lainnya yang dianggap membutuhkan hal yang singkat dan mudah di ingat sebagai pengganti dari nama sebenarnya (Surianto, 2009). Brand is not a logo and $\operatorname{logo}$ is not a brand. Brand is beyond logo. Brand dan logo adalah dua hal yang tidak terpisahkan dan mempunyai fungsi yang saling melengkapi satu sama lain untuk membuat suatu entitas menjadi berbeda dan mempunyai daya saing di antara kompetitornya (Permana, 2012:101).

Sepak Bola adalah sebuah permainan yang dikenal oleh bangsa eropa sebagai 
permainan kelas pekerja. Permainan yang tidak mengenal sekat dan batas kemanusiaan, hanya pada sepak bola lah manusia menjadi satu sama lain. Sejarah mencatat bahwa bangsa Aztec pernah memainkan sebuah permainan yang kurang lebih sama dengan sepak bola sebagai bentuk pemujaannya kepada Yang Maha Kuasa dan akhirnya bangsa Eropa datang dan mempelajari permainan tersebut (Qosasih, 2018: xii).

Indonesia sama sekali tidak terlambat mengenal sepakbola. Para pelaut Portugis memperkenalkan permainan ini di sudut kepulauan banda sekitar abad ke-18. Sementara para pelaut Belanda yang lama pergi dari tanah airnya, pertama kali melihat permainan ini justru di Bandar Jayakarta, kala dimainkan oleh para kuli; dan bukan di Bandar Rotterdam ataupun Genoa. Para kuli pribumi, Melayu, Cina, Arab atau Eropa memainkan bola bersama para pelaut Belanda, Inggris dan Spanyol yang saat itu ramai di Jayakarta. Nusantara telah mengenal sepakbola sejak lama, bahkan ketika kita masih menjadi warga kelas dua dunia. Meski demikan, bangsa kita bukan kelas dua pada dunia sepakbola. Sejarah bahkan tak banyak mencatat nama Eropa yang menjadi kebanggaan di dunia sepakbola, karena nama asli Nusantara atau Cina-lah yang lebih dikenal pada masanya (Qosasih, 2018: xv).

Di Makassar sendiri perkembangan sepak bola sangatlah pesat, itu terbukti dari di dirikannya Makassaarche Voetbalbond atau MVB pada tanggal 2 November 1915 dan menjadi klub sepak bola tertua yang ada di Indonesia. Menurut pengamat sejarah Muh. Nur Imam Martono S.H, sering kedatangan Jepang ke Indonesia pada tahun 1942, banyak hal-hal yang berbau Belanda di hapuskan dan pada tahun 1950 Makassaarche Voetbalbond resmi berganti nama menjadi PSM Makassar.

Fanatisme sepak bola di Makassar bisa dilihat dari supporter yang memadati jalanan kota ketika tim kebanggaan Kota Makassar bertanding, hingga ada yang rela mengeluarkan uang pribadi mereka hanya untuk bertandang ke kandang lawan ketika PSM Makassar bertanding. Menurut Dg. Uki yang merupakan Panglima Kelompok Suporter Laskar Ayam Jantan, PSM Makassar bukan lagi klub sepakbola yang harus di dukung, di teriaki, di soraki, tetapi bagi warga makassar PSM adalah sebuah harga diri yang harus di junjung tinggi dan membela PSM adalah seuatu kewajiban bagi warga Kota Makassar.

Sementara menurut Bpk. Zul Dg. Kulle Selaku presiden dari Kelompok Suporter Redgank mengatakan bahwa PSM Makassar saat ini bukan hanya sebuah tim sepak bola tetapi juga menjadi sebuah identitas bagi masyarakat Sulawesi Selatan khususnya masyarakat Kota Makassar. Bahkan menurut Dg. Kulle ketika orang menyebut Kota Makassar yang pertama terlintas di kepala mereka adalah PSM Makassar bukan lagi tentang Karebosi dan keindahan sunset di Anjungan Pantai Losari.

\section{METODE}

Metode yang digunakan dalam penelitian ini adalah metode observasi. Metode observasi dilakukan dengan melakukan wawancara dan melakukan survey ke kelompok supporter, pemain, dan menejemen PSM Makassar.

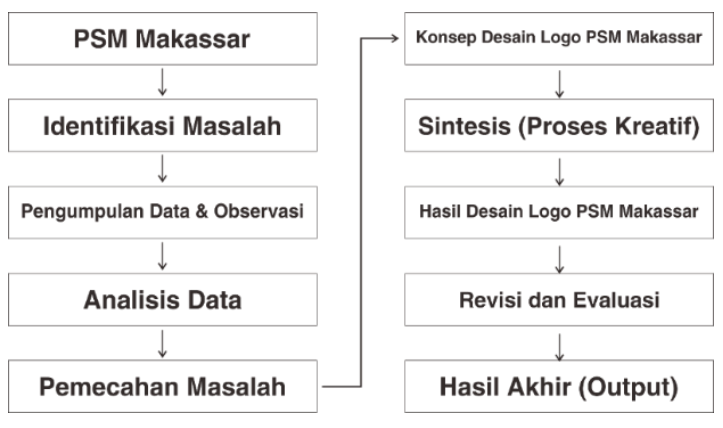

Gambar 2. Alur Perancangan 
Berdasarkan latar belakang dari permasalahan Redesain Visual Identity kali ini, objek/materi komunikasi yang digukanakan akan mengacu pada karakteristik kebudayaan Makassar yang nantinya akan di kembangkan menjadi sebuah konsep perancangan. Warna merah akan mendominasi pada perancangan kali ini kerena seperti yang kita ketahui PSM Makassar dikenal dengan warna merah.

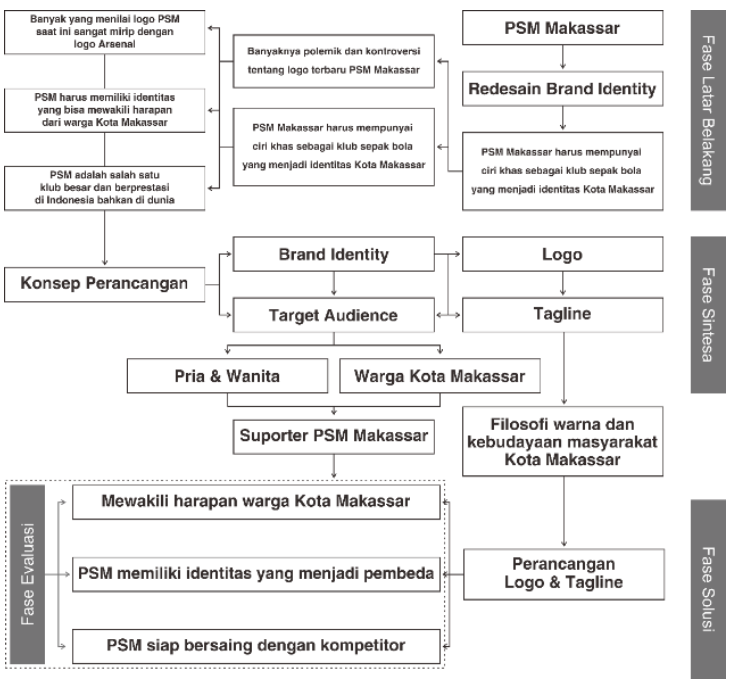

Gambar 3. Mind Mapping

Berdasarkan analisa di lapangan yang berkaitan dengan PSM Makassar, terdapat beberapa data yang menjadi fokus dalam Redesain Visual Identity kali ini, sebagai berikut 1). PSM Makassar adalah salah satu klub sepak bola besar dan berprestasi di Indonesia, 2). PSM Makassar adalah salah satu klub sepak bola yang selalu di perhitungkan di liga Indonesia bahkan di Asia, 3). Permainan yang keras dan cepat serta dipadu dengan teknik tinggi adalah ciri khas permaian dari PSM Makassar, 4). Pemain dan supporter dari PSM Makassar terkenal tangguh dan berani dalam kondisi apapun, 5). "Ewako!" adalah kata penyemangat yang selalu dikumandangkan supporter saat PSM Makassar bertanding, 6). Pemain dari PSM Makassar dikenal tangguh dan memiliki semangat serta motivasi yang tinggi saat bermain, 7). Supporter dari PSM Makassar dikenal memiliki kepribadian keras dan berani, 8). PSM Makassar adalah tim sepak bola tertua di Indonesia, 9). Pada era liga Indonesia PSM Makassar 1 kali menjadi juara yaitu pada tahun 2000 dengan hasil yang sangat mencengangkan yaitu hanya kalah 2 kali dari 31 pertandingan.

\section{HASIL DAN PEMBAHASAN Target Audience}

Supporter PSM Makassar yang cinta dan selalu setia mendukung Persatuan Sepak Bola Makassar (PSM) dan menganggap Persatuan Sepak Bola Makassar (PSM) sudah menjadi identitas bagi warga Kota Makassar. Kelompok supporter yang menjadikan Persatuan Sepak

Bola Makassar (PSM) sebuah harga diri yang harus di junjung tinggi dan membela Persatuan Sepak Bola Makassar (PSM) adalah seuatu kewajiban bagi warga Kota Makassar.

\section{Konsep Desain}

Konsep desain adalah ide di balik sebuah desain. Konsep ini akan mendasari logika, pemikiran serta penalaran dalam mendesain. Dalam redesain visual Identity PSM Makassar kali ini mengusung konsep "Semangat Kejayaan". Semangat kejayaan adalah suatu istilah yang menggambarkan mengenai suatu sikap dimana seseorang atau kelompok yang memiliki semangat dan ambisi dalam berjuang mencapai tujuannya serta memiliki tekad yang kokoh untuk terus berjuang demi mendapat kejayaannya.

Seperti yang diketahui Persatuan Sepak Bola Makassar (PSM) adalah klub besar di Indonesia yang setiap musimnya selalu di perhitungkan di liga Indonesia bahkan di asia dan menjadi salah satu tim dengan prestasi paling stabil di liga Indonesia. Masa kejayaan PSM Makassar adalah saat menjadi juara liga 
Indonesia pada tahun 2000 dengan hasil yang sangat mengesankan hanya kalah 2 kali dari 31 pertandingan. Sementara di level internasional Persatuan Sepak Bola Makassar (PSM) tercatat 1 kali berlaga di Piala Winner Asia dan 3 kali mewakili indonesia di liga Champion Asia bahkan Persatuan Sepak Bola Makassar (PSM) pernah lolos ke perempat final liga Champion Asia pada tahun 2000.

\section{Konsep Visual Branding}

Visual Branding yang digunakan pada redesain kali ini untuk menghasilkan ciri khas, karakter, gaya visual, persepsi target audiens dengan memanfaatkan elemen visual berupa warna, simbol, dan teks yang diharapkan dapat menjadi identitas dan pembeda klub Persatuan Sepak Bola Makassar (PSM) dengan klub sepak bola lain yang ada di Indonesia bahkan di dunia.

\section{Warna}

Adapun warna utama yang akan digunakan dalam redesain visual identity PSM Makassar adalah:

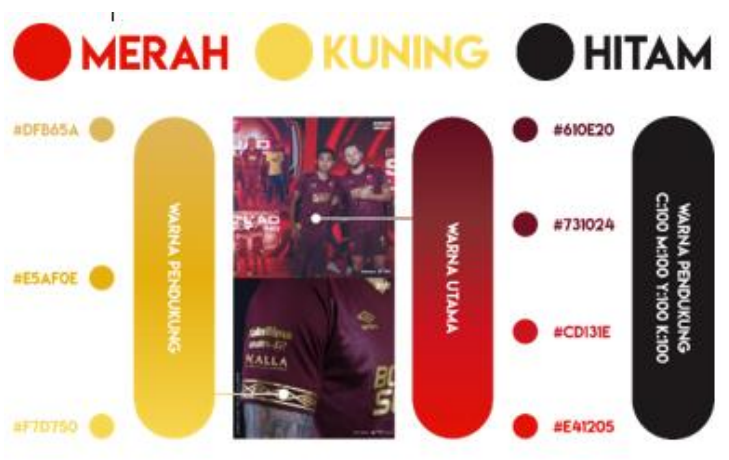

Gambar 4. Pilihan Warna

Merah sebagai warna utama yang melambangkan semangat, gairah dan energi. Pemilihan warna merah diharapkan dapat membakar semangat dan energi para pemain serta menambah gairah Persatuan Sepak Bola Makassar (PSM) agar selalu mendapatkan hasil positif di setiap pertandingannya. Warna merah juga sangat identik dengan Persatuan Sepak Bola Makassar (PSM).

Kuning keemasan sebagai warna pendukung melambangkan kebahagiaan, harapan, positif dan kejayaan. Pemilihan warna Kuning keemasan diharapkan dapat membuat Persatuan Sepak Bola Makassar (PSM) selalu mendapatkan hasil positif. Pemilihan warna kuning keemasan juga melambangkan bahwa Persatuan Sepak Bola Makassar (PSM) adalah klub sepak bola yang penuh dengan prestasi.

Hitam sebagai warna pendukung melambangkan kekuatan. Pemilihan warna hitam diharapkan dapat membuat para pemain Persatuan Sepak Bola Makassar (PSM) selalu menampilkan permainan terbaiknya di setiap pertandingan.

\section{Sketsa Logo}

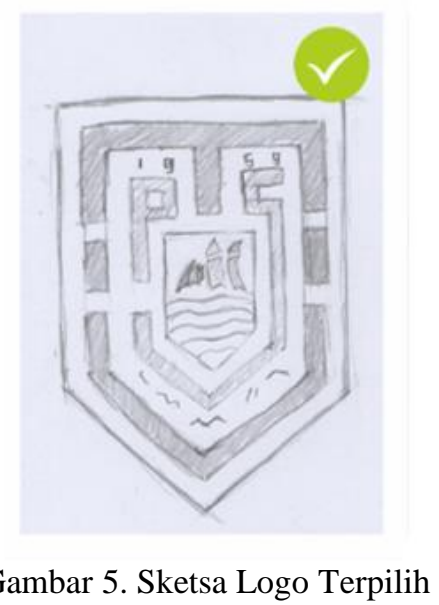

Sketsa yang terpilih melalui petimbangan bahwa logo yang dirancang dapat mewakili harapan supporter, pemain dan manajemen Persatuan Sepak Bola Makassar (PSM). Sketsa yang dipilih juga karna dapat mewakili ciri khas, karakter, gaya visual yang mengacu pada kebudayaan Kota Makassar serta terlihat lebih modern, simple dan tentunya tidak terlepas dari karakter Persatuan Sepak Bola Makassar (PSM). Tipografi yang akan digunakan diambil dari bentuk dasar Aksara Lontara. Ketegasan 
Aksara Lontara di setiap hurufnya memiliki karakter dan memberikan keunikan tersendiri. Ketegasan Aksara Lontara dipadukan dengan karakter tipografi sans serif yang modern dan simpel.

\subsection{Digitalisasi Logo}

Setelah proses sketsa berikutnya adalah proses digitalisasi logo:
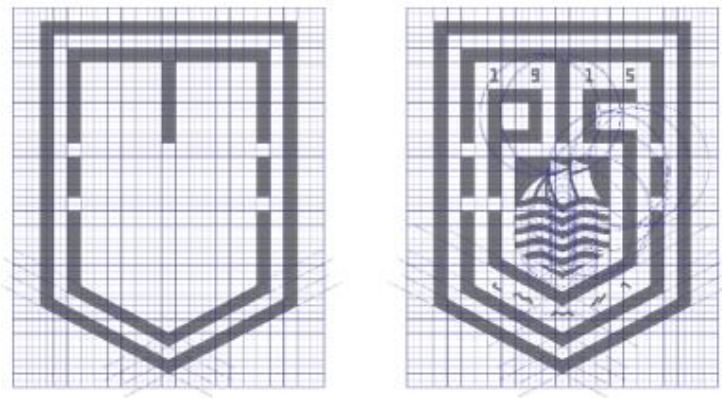

Gambar 6. Digitalisasi Logo

\subsection{Pemilihan Warna}

Tahap berikutnya adalah proses digitalisasi warna. Warna untuk logo yang dibuat diambil sesuai dari palet warna yang sudah ditentukan. Berikut adalah hasil dari digitalisasi warna:

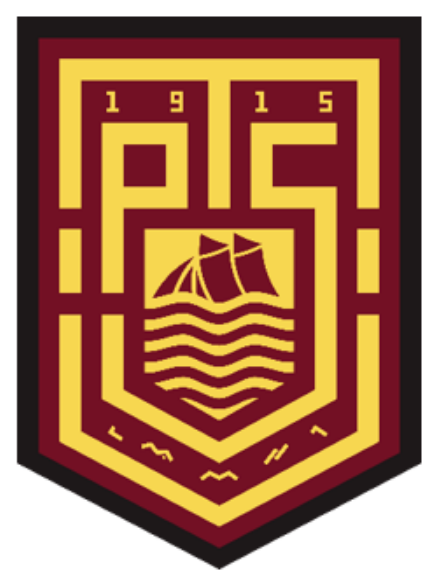

Gambar 6. Pewarnaan Logo

\subsection{Perancangan Typeface}

Berikutnya adalah perancangan typeface yang sesuai dengan karakter logo terpilih. Berikut adalah typeface yang di rancang:

\section{ABCDEFGHIJKLII ПOPAR5TUUWXYZ 1234567890}

Gambar 7. Typeface

\subsection{Perancangan Icon Set}

Berikutnya adalah perancangan icon set sesuai dengan karakter dari logo yang terpilih. Berikut adalah icon set yang dirancang:

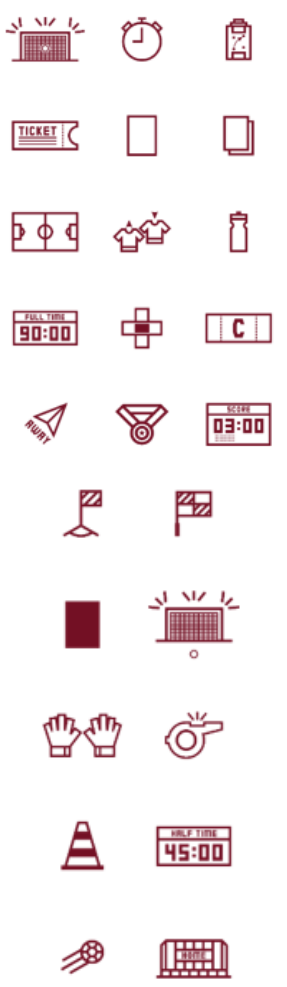

Gambar 8. Icon-icon 
Skala dan Clean Space Area Logo

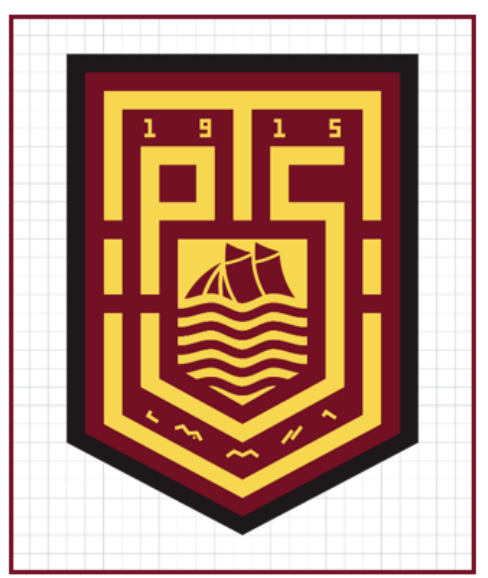

Gambar 9. Scala dan Cleas space Area Logo

\subsection{Signature Positif dan Negatif}
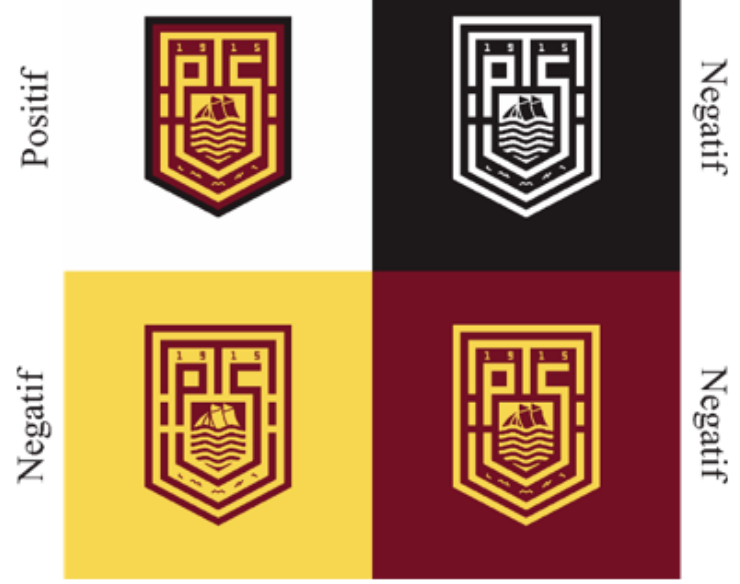

Gambar 10. Positif dan Negatif Logo

Ukuran Minimum Penggunaan Logo Formulasi Warna

Formulasi warna adalah tahap untuk menentukan pengaplikasian warna yang pas pada logo seperti berikut:

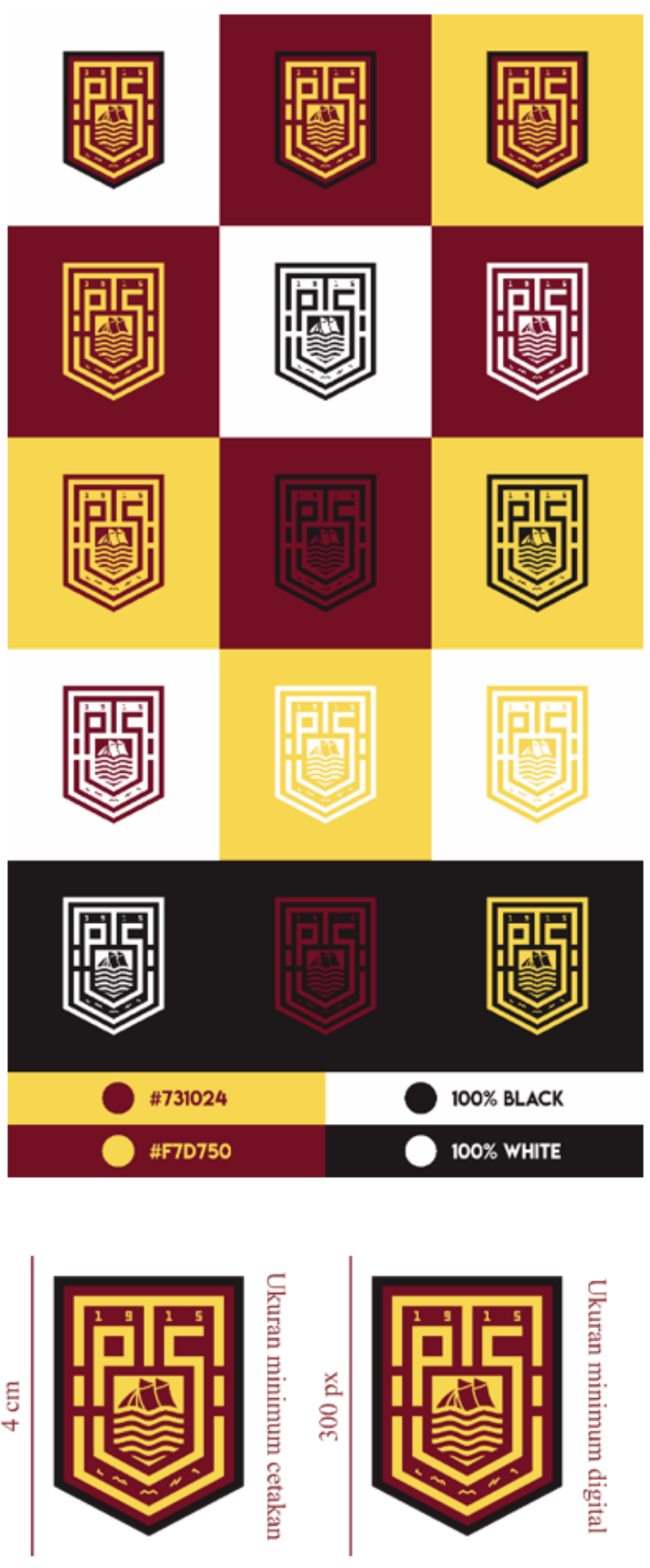

Gambar 11. Ukuran Penggunaan Logo 


\section{Larangan Penyalahgunaan pada logo} logo:

Larangan Penyalahgunaan warna pada

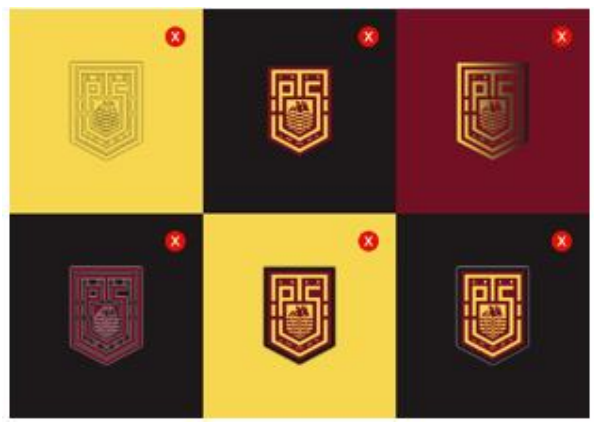

Gambar 11. Larangan Penggunaan Warna

Larangan Penyalahgunaan bentuk pada logo:

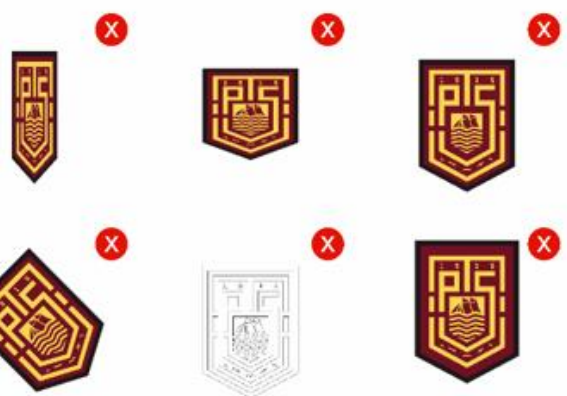

Gambar 12. Larangan Penggunaan Bentuk logo:

Larangan Penyalahgunaan motif pada

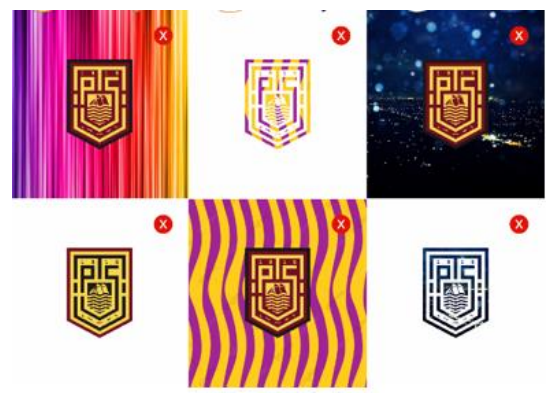

Gambar 13. Larangan Penggunaan Motif

\section{Benchmarking}

Benchmarking logo adalah perbandingan kekuatan karakter pada logo dan juga menjadi acuan untuk menentukan positioning dengan competitor lainnya:

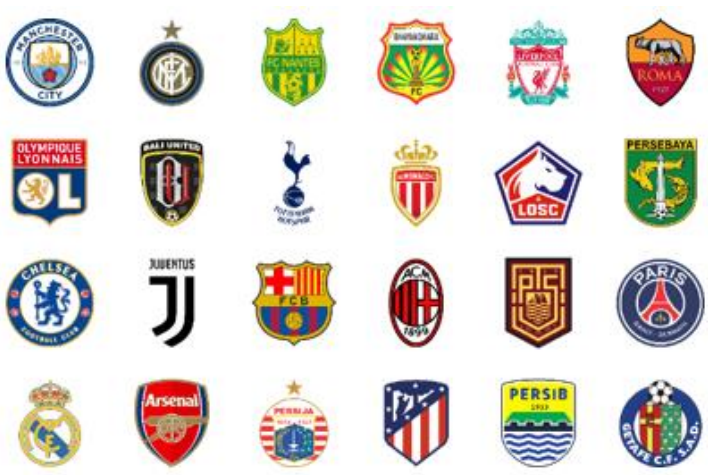

Gambar 14. Benchmarking Logo

\section{Media Utama}

Media utama dalam perancangan ini adalah sebuah logo yang dapat menjadi identitas Persatuan Sepak Bola Makassar (PSM) dan mewakili harapan warga kota Makassar khususnya harapan supporter, pemain dan manejemen dari Persatuan Sepak Bola Makassar (PSM). Logo yang dirancang juga diharapkan dapat menjadi pembeda Persatuan Sepak Bola Makassar (PSM) dengan klub sepak bola lain yang ada di Indonesia dan bahkan di dunia.

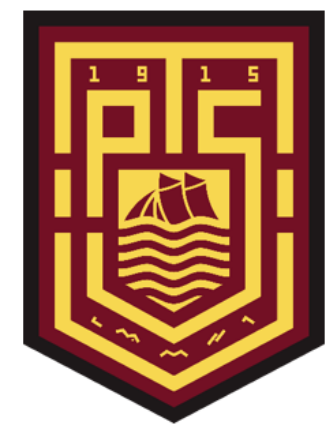

Gambar 15. Final Logo 


\section{Media Pendukung}

Media pendukung dalam perancangan ini adalah beberapa peralatan yang dapat digunakan oleh pemain dan manejemen Persatuan Sepak Bola Makassar (PSM) serta beberapa merchandise yang dapat digunakan untuk para supporter Persatuan Sepak Bola Makassar (PSM).
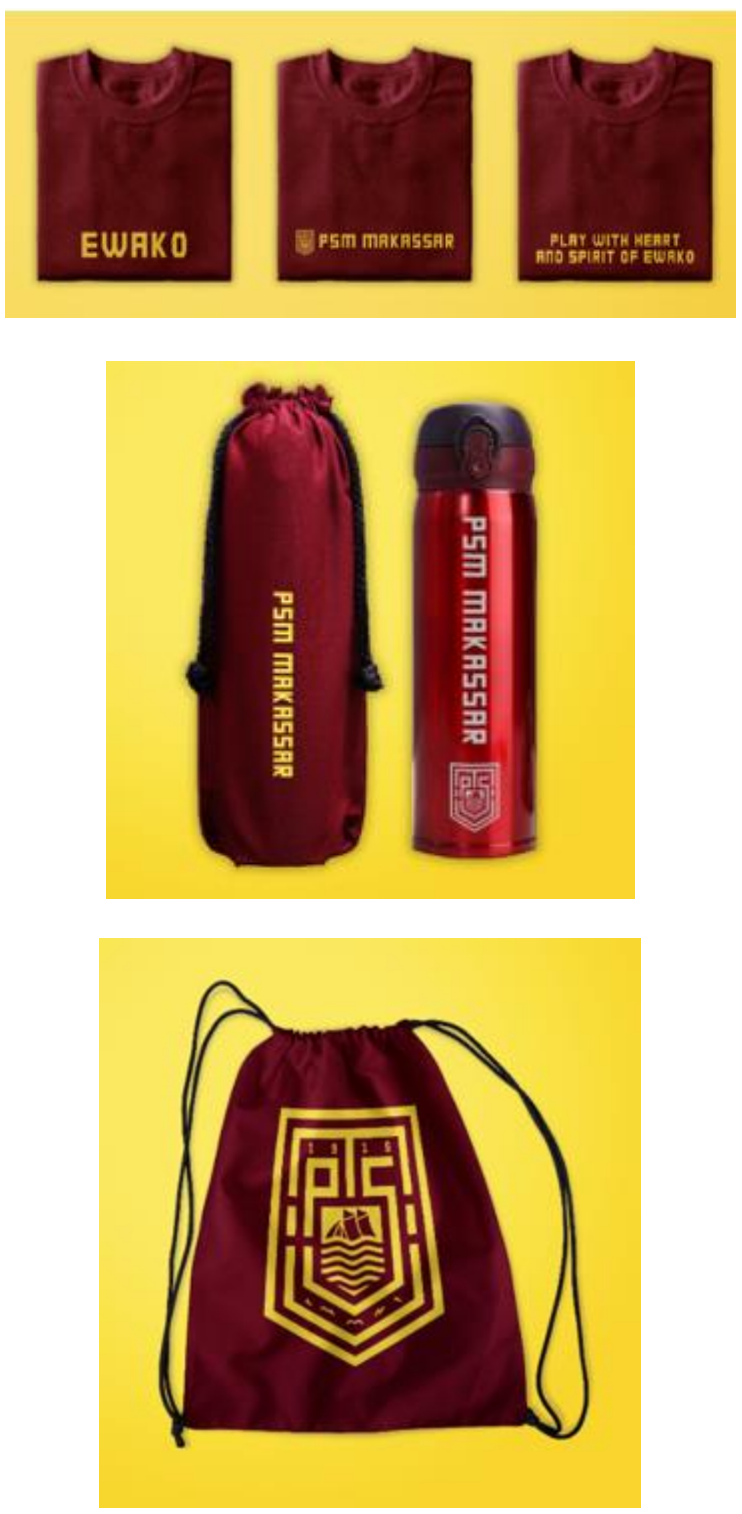

Gambar 16. Media Pendukung, Kaos, Thumbler, dan Tas Serut

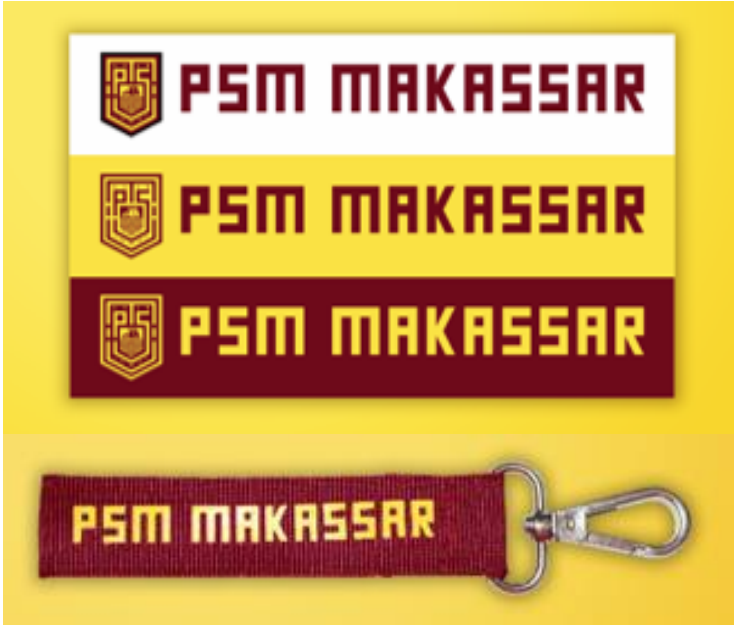

Gambar 17 Media Pendukung, Stiker dan Gantungan Kunci

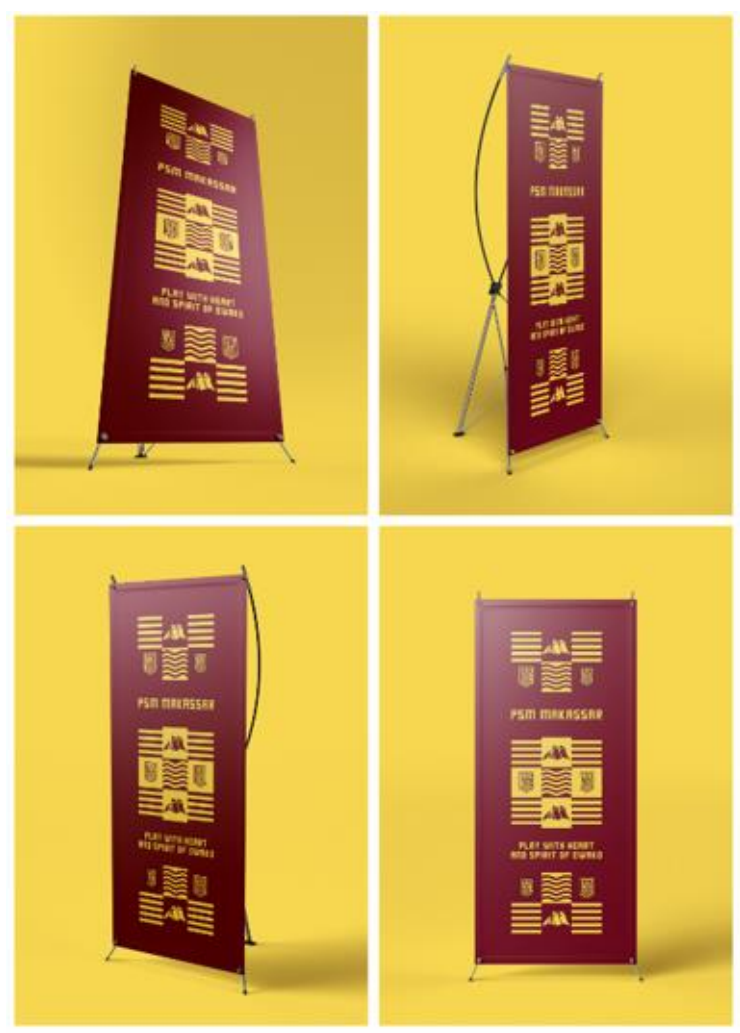

Gambar 18. Media Publikasi X Banner 


\section{KESIMPULAN DAN SARAN Kesimpulan}

Berdasarkan proses dan hasil dari Redesain Visual Identity PSM Makassar yang dilakukan dapat ditarik kesimpulan sebagai berikut:

1. Redesain Visual Identity PSM Makassar dengan konsep dan bentuk visualisasi yang jelas dapat membuat Persatuan Sepak Bola Makassar (PSM) memiliki identitas yang menjadi pembeda dari klub sepakbola lainnya yang ada di Indonesia bahkan di dunia.

2. Dari data dan fakta yang telah di kumpulkan dapat di simpulkan bahwa Persatuan Sepak Bola Makassar (PSM) klub sepakbola yang memiliki banyak prestasi di Indonesia dan bahkan di kancah internasional. Sepak Bola Makassar (PSM) setiap musimnya selalu di perhitungkan di liga Indonesia bahkan di asia dan menjadi salah satu tim dengan prestasi paling stabil di liga Indonesia.

3. Perkembangan sepakbola di Makassar sangatlah pesat itu terbukti dari di dirikannya Makassaarche Voetbalbond atau MVB pada tanggal 2 November 1915 dan menjadi klub sepak bola tertua yang ada di Indonesia.

4. Fanatisme sepak bola di Makassar bisa dilihat dari supporter yang memadati jalanan kota ketika tim kebanggaan Kota Makassar tersebut bertanding, hingga ada yang rela mengeluarkan uang pribadi mereka hanya untuk bertandang ke kandang lawan ketika Persatuan Sepak Bola Makassar (PSM) bertanding karena mereka beranggapan bahwa Persatuan Sepak Bola Makassar (PSM) bukan lagi klub sepakbola yang harus di dukung, di teriaki, di soraki, tetapi bagi warga Makassar khususnya para supporter Persatuan Sepak Bola Makassar (PSM) adalah sebuah harga diri yang harus di junjung tinggi dan membela Persatuan
Sepak Bola Makassar (PSM) adalah seuatu kewajiban bagi warga Kota Makassar.

5. Dari hasil penelitian dapat pula disimpulkan bahwa kota Makassar sangat identik dengan Persatuan Sepak Bola Makassar (PSM) karena ketika orang menyebut tentang Makassar yang pertama terlintas di kepala mereka adalah Persatuan Sepak Bola Makassar (PSM) bukan lagi tentang Karebosi dan keindahan sunset di Anjungan Pantai Losari.

6. Redesain Visual Identity PSM Makassar dengan konsep dan bentuk visualisasi yang jelas dapat membuat Persatuan Sepak Bola Makassar (PSM) dapat mewakili harapan warga kota Makassar khususnya untuk para supporter.

7. Ciri khas, karakter, gaya visual, persepsi target audiens dengan memanfaatkan elemen visual berupa warna, simbol, dan teks dari budaya warga kota Makassar dapat menjadi identitas dan pembeda klub Persatuan Sepak Bola Makassar (PSM) dengan klub sepak bola lain yang ada di Indonesia bahkan di dunia.

8. Membuat sebuah karya Desain Komunikasi Visual yang cepat dilirik oleh publik barangkali terlalu sulit, namun output visual yang unik, menyentuh dan menggugah emosi publik adalah jenjang kreativitas yang berbeda.

\section{Saran}

Terlepas dari keterbatasan yang dimiliki, hasil dari redesain kali ini diharapkan memiliki perngaruh yang besar bagi Persatuan Sepak Bola Makassar (PSM) dan dapat menjadi referensi untuk penelitian selanjutnya dengan topik yang serupa. Adapun saran dari hasil perancangan kali ini untuk penelitian selanjutnya adalah:

1. Penelitian yang akan dilakukan selanjutnya sebaiknya lebih memperluas wawasan mengenai persoalan merek/brand, mulai 
dari pemaknaan kata dan tahapan-tahapan yang menyangkut proses branding.

2. Penelitian selanjutnya juga sebaiknya harus lebih memahami target audience demi memenuhi hasil dan harapan yang di inginkan dari penelitian yang dilakukan.

3. Penelitian selanjutnya sebaiknya juga perlu memperluas wawasan mengenai ilmu semiotika dalam dunia Desain Komunikasi Visual.

4. Penetlitan sebaiknya berfokus pada prosesnya bukan pada hasil akhirnya karna desain yang baik adalah desain yang memenuhi fungsinya.

5. Penelitian selanjutnya sangat perlu mempertimbangkan kekuatan budaya setempat untuk menciptakan karakter desain yang memiliki identitas.

\section{DAFTAR PUSTAKA}

Cahyadi, D. (2016). PERANCANGAN TYPEFACE AKSARA LATIN BERDASARKAN AKSARA LONTARA BUGIS-MAKASSAR. Makassar: Fakultas Seni dan Desain Universitas Negeri Makassar .

Gaspar, R. (2018). Sepak bola The Indonesia Way of Life. Jakarta: CV. Kawos Publising.

Hady Yuliartha, N. I. (2017). 1. Strategi Komunikasi Pemasaran Terpadu Bali United Dalam Membangun Brand Image Sebagai Klub Sepak Bola Profesional . Bali: Fakultas Ilmu Sosial dan Ilmu Politik Universitas Udayana .

Kartika, Jessica D., R. (2015). Logo : Visual Asset Development. Jakarta: PT. Elex Media Komputindo.
Kulle, D. (2019, March 24). PSM bagi warga Kota Makassar. (B. A. Budiman, Pewawancara)

Martono, M. N. (2019, April 8). Sejarah PSM Makassar. (B. A. Budiman, Pewawancara)

Permana, I. (2012). Brand Is Like a DOnut. Jakarta: PT. Bhuana Ilmu Populer.

Priyanto, D. (2018). Perancangan Branding \& Marchendise PSS Sleman. Yogyakarta: Program Studi Pendidikan Seni Rupa, Fakultas Bahasa dan Seni, Universitas Negeri Yogyakarta.

Qosasih, A. (2018). Sepak bola The Indonesia Way Of Life. Jakarta: CV.Kawos Publishing.

S.H, M. N. (2019). Sejarah PSM Makassar. Makassar.

Said, A. A. (2006). Dasar Desain Dwimatra. Makassar: Badan Penerbit UNM.

Scheunemann, T. (2018). Sepak bola The Indonesia Way Of Life. Jakarta: CV. Kawos Publising.

Surianto, R. (2009). Mendesain Logo. Jakarta: PT. Gramedia Pustaka Utama.

Sutton, A. (2018). Sepak bola The Indonesia Way Of Life. Jakarta: Cv. Kawos Publishing.

T, R. E. (2017). Perancangan Brand Identity Jalangkote Lahalede. Makassar: Fakultas Seni dan Desain Universitas Negeri Makassar. 
Baso Azwan Budiman, Redesain Visual Identity PSM Makassar

Uki, D. (2019, March 24). PSM bagi warga

Kota Makassar. (B. A. Budiman, Pewawancara)

Wirawan, M. B. (2008). Kamus Brand A-Z. Jakarta: Red \& White Publishing. 